\title{
Radiological signs of a true lunate dislocation
}

\author{
Adam Tucker, William Marley, Angel Ruiz
}

Department of Trauma and Orthopaedics, Altnagelvin Area Hospital, Londonderry, UK

\section{Correspondence to}

Adam Tucker,

atuc@hotmail.com
To cite: Tucker $A$, Marley W, Ruiz A. BMJ Case Rep Published online: [please include Day Month Year] doi:10.1136/bcr-2013009446

\section{DESCRIPTION}

Perilunate dislocations are high-energy injuries that are uncommon. The literature suggests that up to $25 \%$ of cases may be missed. ${ }^{12}$ Here we present an acute lunate dislocation in a young man who fell from a height of 12 feet onto an extended, outstretched right hand. Plain radiographs demonstrated classical signs of a perilunate dislocation (figures 1 and 2). He also sustained fractures of the radial and ulnar styloid, indicating a variant of a greater arc injury. ${ }^{3}$ Following a failed closed reduction the patient proceeded to open reduction and percutaneous Kirschner wire fixation, with repair of the inter-carpal ligaments.

True lunate dislocation is stage 4 of the Mayfield's classification. Key radiological findings include:

1. Dislocation of the lunate from the lunate fossa (usually volar) into the space of poirier, also known as the 'spilled tea cup' sign, with loss of colinearity of the radius, lunate and capitate

2. Interruption of Gilula's lines

3. The 'piece of pie' sign representing the lunate on true Anteroposterior (AP) x-ray views

4. Lunate and capitate overlap

5. An abnormal scapho-lunate angle of $>70$ or $<30^{\circ}$.

Figures 3 and 4 demonstrate the features outlined above, and knowledge of these will reduce the risk of missing these significant injuries. These

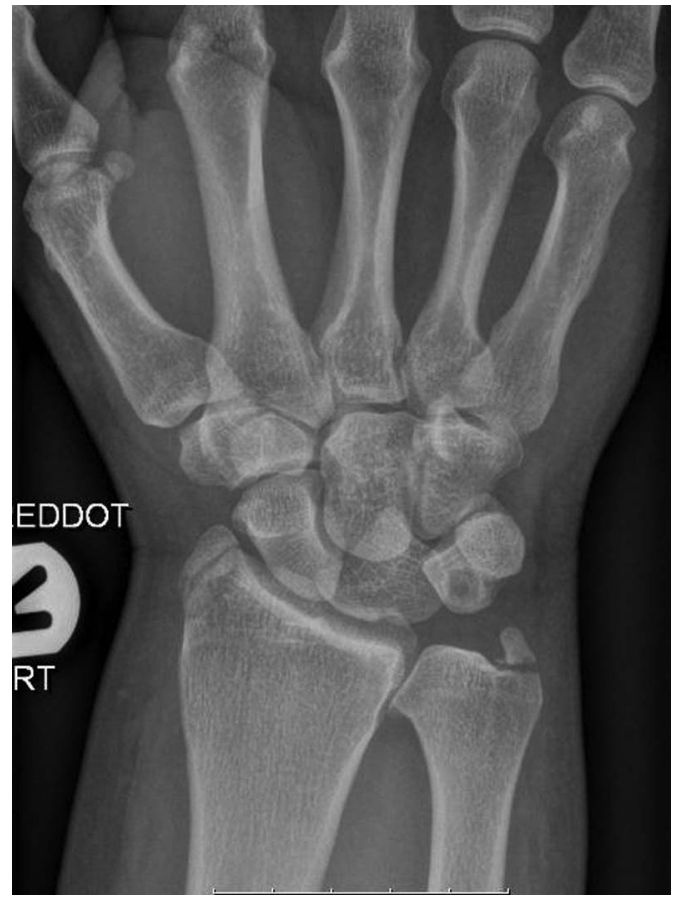

Figure 1 Anteroposterior (AP) view of the wrist. are important injuries to recognise as complications include median nerve injury, long-term carpal instability and chronic pain. ${ }^{23}$

At the patient's last clinic review, the K-wire was kept in situ. Plain x-ray demonstrates a reduced lunate. He remains under clinical follow-up.

\section{Learning points}

- Up to $25 \%$ of these injuries are missed, with catastrophic long-term consequences for the patient. Therefore, open reduction with repair of the ligamentous structure is often required.

- Knowledge of the classical radiological features of lunate dislocation - particularly the 'spilt tea cup' sign, the 'piece of pie' sign and loss of Gilula's lines. Associated injuries can also be present, which may distract the clinician and result in a missed diagnosis of a lunate dislocation.

- Knowledge of the above signs is essential in preventing delayed, or missed diagnosis.

Competing interests None.

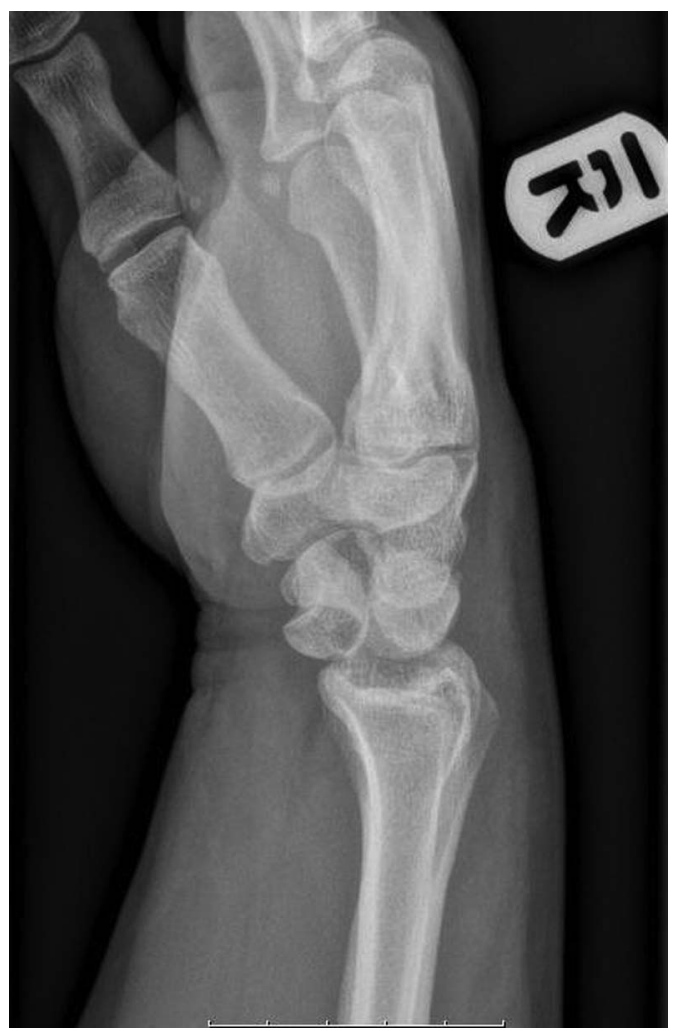

Figure 2 Lateral view of the carpus. 


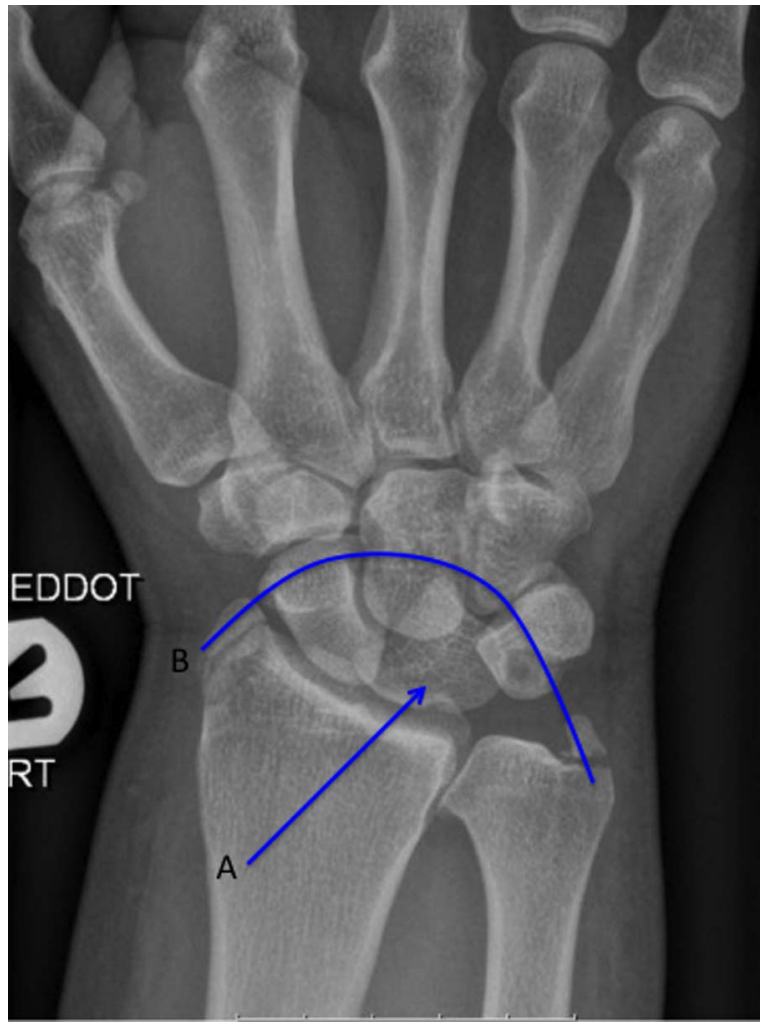

Figure 3 Annotated AP view of the wrist. The 'piece of pie' classical triangular shape of the lunate is seen (arrow A), with associated greater arc injury with fractures of the radial and ulnar styloid, and interruption of Gilulas lines (labelled B).

\section{Patient consent Obtained.}

Provenance and peer review Not commissioned; externally peer reviewed.

\section{REFERENCES}

1 Herzberg G, Comtet JJ, Linscheid RL, et al. Perilunate dislocations and fracture dislocations: a multicenter study. J Hand Surg [Am] 1993;18:768-79.

2 Newberry JA, Garmel GM. Image diagnosis: perilunate and lunate dislocations. Perm J 2012;16:70-1.

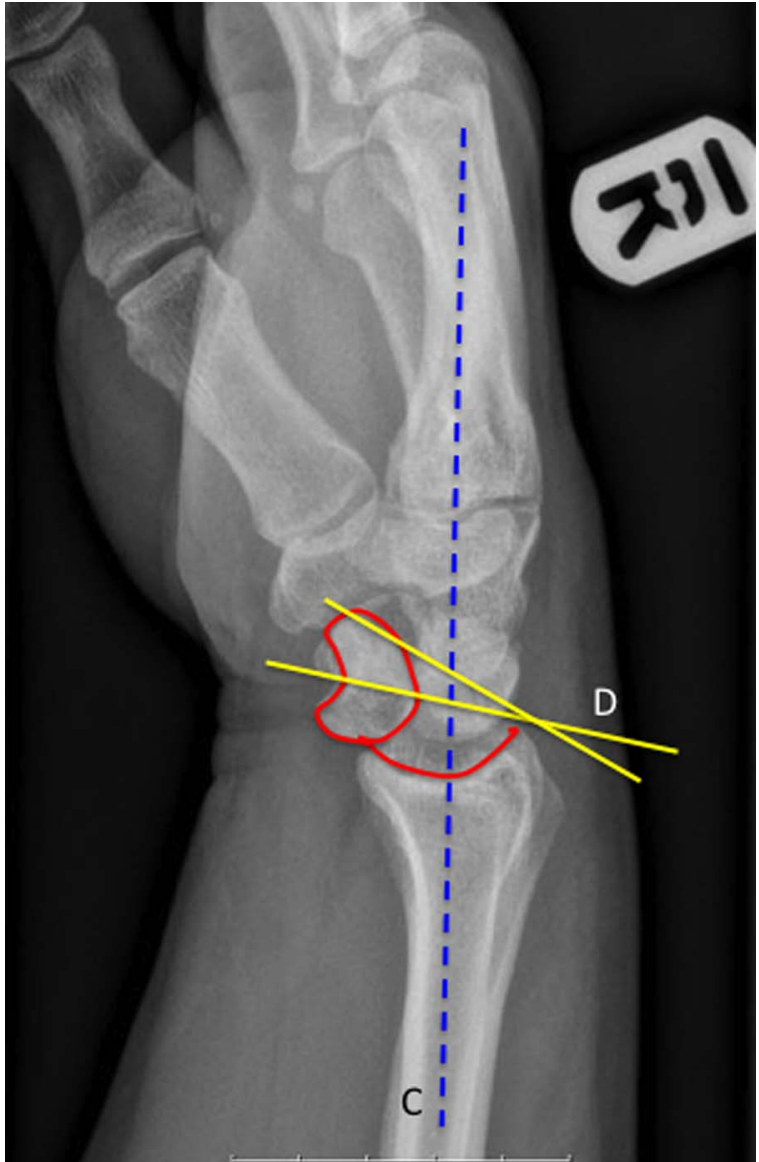

Figure 4 Annotated lateral view of the carpus. The 'spilt tea cup' sign can be seen (in red) as the lunate is rotated and displaced volarly with respect to the radial articular surface, with subsequent loss of colinearity (line C) where the lunate does not lie on the collinear axis. The scapolunate angle (D) is abnormal (normal range $30-60^{\circ}$ ), and the hamate and lunate overlap.

3 Gaebler C. Fractures and dislocations of the carpus. In: Bucholz RW, Heckman JD, Court-Brown C, Tornetta P, Koval KJ.eds Rockwood and Green's fractures in adults. Philadelphia: Lippincott Williams \& Wilkins, 2005;857-908.

Copyright 2013 BMJ Publishing Group. All rights reserved. For permission to reuse any of this content visit

http://group.bmj.com/group/rights-licensing/permissions.

BMJ Case Report Fellows may re-use this article for personal use and teaching without any further permission.

Become a Fellow of BMJ Case Reports today and you can:

- Submit as many cases as you like

- Enjoy fast sympathetic peer review and rapid publication of accepted articles

- Access all the published articles

- Re-use any of the published material for personal use and teaching without further permission

For information on Institutional Fellowships contact consortiasales@bmjgroup.com

Visit casereports.bmj.com for more articles like this and to become a Fellow 